\title{
Efficacy of Non-invasive Brain Stimulation Methods for the Treatment of Cognitive Impairment in Traumatic Brain Injury and Stroke
}

\author{
Travmatik Beyin Hasarı ve İnmede Kognitif Bozuklukların Tedavisinde Non-invaziv \\ Beyin Stimülasyon Yöntemlerinin Etkinliği
}

\author{
Ankara Yildirim Beyazit University Institute of Health Sciences, Department of Speech and Language Therapy; Department of \\ Neuroscience, Ankara, Turkey
}

\begin{abstract}
Cognitive impairments are pervasive among populations with traumatic brain injury and cerebral vascular accidents. Given the limited effectiveness of behavioral approaches in treating cognitive impairments, the use of non-invasive brain stimulation and modulation methods have been increasingly explored over the past decade. The present article reviews recent evidence on the use of two non-invasive technologies, transcranial magnetic stimulation and transcranial direct current stimulation on populations with brain injury and stroke. The results indicate that although evidence for the use of neuromodulation for cognitive enhancement in neurotypical adults is somewhat positive, its use in disordered populations is less promising. Few studies demonstrated positive effects of neuromodulation on cognitive measures. Importantly, most results are confounded by behavioral interventions and the effects are highly variable. More research is needed to evaluate the therapeutic potential of non-invasive brain stimulation techniques when used in isolation for remediation of cognitive impairments associated with various neurologic conditions. Larger clinical trials with strong methodologic rigor including double-blind randomized control trials are necessary to validate the use of these methods for translational implementation. Given the conflicting evidence base that presently exists, when neuromodulation techniques are employed, they should be used with cognitive and physical therapies that are given precedence.
\end{abstract}

Keywords: Rehabilitation, traumatic brain injuries, stroke, cognitive impairment, non-invasive brain stimulation

\section{Öz}

Kognitif bozukluklar, özellikle travmatik beyin hasarı ve serebrovasküler olay geçirmiş bireylerde yaygındır. Kognitif bozuklukların tedavisinde, rehabilitasyon yaklaşımlarının etkinliği sınırlıdır. Bu alanda son on yılda, invaziv olmayan beyin stimülasyonu ve modülasyon yöntemlerinin kullanımı giderek daha fazla artmıştır. Bu makale, iki invaziv olmayan teknolojinin, transkraniyal manyetik stimülasyonun ve transkraniyal doğru akım stimülasyonunun beyin hasarı ve inme geçirmiş olan popülasyonlarda kullanımına ilişkin son çalışmaları ve kanıtları gözden geçirmektedir. Sonuçlar, nörotipik yetişkinlerde kognitif gelişim için nörostimülasyon kullanımına yönelik kanıtların daha pozitif olduğunu, kaza veya inme geçirmiş popülasyonlarda ise kullanımının yeterince sonuç veremediğini göstermektedir. Literatürde, nörostimülasyonun kognitif ölçütler üzerindeki olumlu etkisini ortaya koyan kısıtlı sayıda çalışma vardır. Sonuçların birçoğu, rehabilitatif müdahalelerle karıştırılmaktadır ve etkileri oldukça değişkendir. İnvaziv olmayan beyin stimülasyon tekniklerinin, kognitif bozuklukların giderilmesinde, tek başına kullanıldığında terapotik potansiyelini değerlendirmek için daha fazla araştırmaya ihtiyaç olduğu bir gerçektir. Çift-kör randomize kontrollü araştırmalar da dahil olmak üzere güçlü metodolojisi olan daha büyük klinik deneyler, bu yöntemlerin translasyonel uygulama için kullanımını doğrulamak için gereklidir. Çelişkili kanıt temeli göz önüne alındığında, nörostimülasyon teknikleri kullanıldı̆̆ında öncelik kognitif ve fiziksel tedavilere verilmelidir.

Anahtar Kelimeler: Rehabilitasyon, travmatik beyin hasarlar1, inme, kognitif bozukluk, invaziv olmayan beyin stimülasyon

\section{Introduction}

Neuroplasticity is the brain's ability to remodel itself by forming new synaptic connections in response to experiences throughout life (1). One method by which neuroplasticity can be exploited is non-invasive cortical stimulation. Ample evidence demonstrates the effectiveness of different non-invasive brain stimulation methods on rehabilitation in animal models of disease; however, the utility of these methods in humans is less

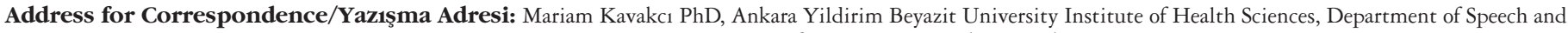
Language Therapy; Department of Neuroscience, Ankara, Turkey

Phone: +90 5351094247 E-mail: mariamkavakci@gmail.com ORCID: orcid.org/0000-0001-6511-9203

Received/Geliş Tarihi: 27.05.2020 Accepted/Kabul Tarihi: 21.01.2021

${ }^{\circ}$ Copyright 2021 by Turkish Neurological Society

Turkish Journal of Neurology published by Galenos Publishing House. 
clear $(2,3,4,5)$. Exploratory work on human subjects indicates noninvasive brain stimulation methods may be a promising method for accelerating processing speed and various memory abilities in healthy individuals, particularly following repeated administration $(6,7,8,9)$. These methods have also been considered as a potential supplement to behavioral and physical therapies for providing a cognitive boost during rehabilitation $(10,11)$.

Currently, the most widely used methods for neuromodulation are transcranial magnetic stimulation (TMS) and transcranial direct current stimulation (tDCS). These techniques can induce long-term neural changes including cortical reorganization and plasticity by modulating cortical regions and networks when administered repeatedly (12). A few technical distinctions between different types of TMS and tDCS are worth mentioning. Although both are non-invasive methods that operate on the principle of electromagnetic induction, they differ in that single-pulse TMS operates on stimulatory mechanisms that can provoke action potentials while repetitive TMS (rTMS) and tDCS can instigate modulation by way of a low amplitude current $(13,14)$. Also worth noting is the difference in the extent of stimulation provided by TMS and tDCS. TMS typically targets a more focal area as a result of the particular coil used (i.e., figure-eight) and tDCS delivers more diffuse stimulation via a montage (Figure 1) consisting of an anode and cathode (15). For this general review, the term neuromodulation will be used for both methods henceforth. In the following sections, a general review is provided of the recent evidence on the use of TMS and tDCS in cognitive improvements of patients with (1) traumatic brain injury (TBI) and (2) stroke.

\section{Search Method}

The literature search was performed on MEDLINE/PubMed and Web of Science online databases. On PubMed, the following MeSH terms: ((traumatic brain injury [MeSH Terms]) or (TBI $[\mathrm{MeSH}$ Terms])) or ((stroke [MeSH Terms]) and ((tDCS[MeSH Terms]) or (Transcranial Direct Current Stimulation [MeSH Terms]) or ((TMS [MeSH Terms])) or (Transcranial Magnetic Stimulation [MeSH Terms]). Only studies over the last 5 years were included to provide the most up-to-date review (filtered by date (1/1/2014 to $12 / 31 / 2019)$. Titles and abstracts were reviewed to ensure studies reflect the topic of the review. Eligible studies fulfilled the following criteria: experimental studies on healthy
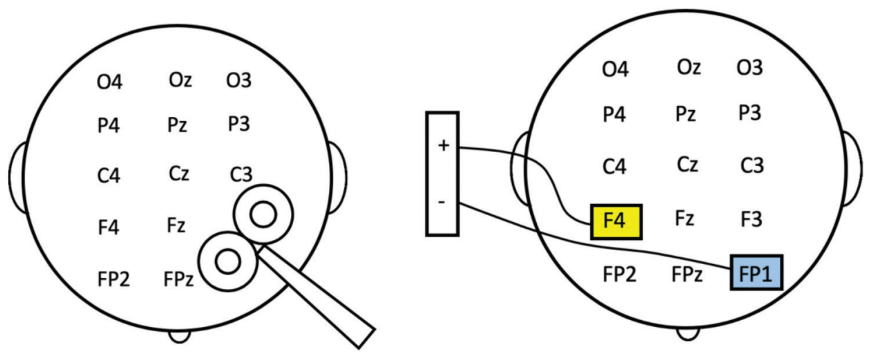

Figure 1. Examples of TMS coil application (left) and tDCS montage (right) showing a positive anode electrode in yellow and a negative cathode in blue

TMS: Transcranial magnetic stimulation, tDCS: Transcranial direct current stimulation individuals or adults with TBI and/or stroke who received tDCS and/or TMS for therapeutic purposes. Studies that did not meet these criteria, screened first by title, then abstract, then by full text and case reports, were excluded.

\section{Traumatic Brain Injury Studies}

TBI is defined by the centers for disease control and prevention as a "bump, blow or jolt to the head, or penetrating head injury, that results in disruption of the normal function of the brain" that can result from a wide range of injuries (16). Due to the high incidence and detrimental consequences of TBI coupled with the limited effectiveness of cognitive therapies, neuromodulation work has prioritized research in this patient population. Positive findings on the effectiveness of TMS with neurotypical individuals has also attracted attention to this area (9). In an animal model of pediatric TBI, Lu et al. (4) found that TMS effectively increased neural responses that were hypoactive post-injury as measured by functional magnetic resonance imaging. The same group of rats that received TMS therapy also demonstrated positive behavioral changes (i.e., reductions in hyperactivity) compared with the control group.

Results from clinical human studies are less convincing. In a randomized double-blind study of patients with severe TBI with diffuse axonal injury, executive function ability as measured by a trail-making test did not differ from patients in the sham (placebo) condition after rTMS was applied to the dorsolateral prefrontal cortex (17). Another randomized double-blind study investigated the effect of anodal tDCS on cognitive rehabilitation of patients with subacute TBI (18). In addition to electrencephalography (EEG) oscillations, outcome measures included performance on tests of working memory, cognitive flexibility, inhibition, verbal and visuo-spatial memory (immediate and delayed), emotion recognition, and attention. Improvements were documented in both sham and active groups. There were no significant differences between the groups on any of the measures. The only significant finding was a correlation between improvement on the measures and change in cortical excitability in the active group.

Recently, there has been a special focus on neuromodulation in patients with TBI with consciousness impairments. Estraneo et al. (19) measured coma recovery scale-revised (CSR-R) scores and EEG changes in patients with TBI who received five active and five sham tDCS sessions and found no improvements in either outcome measure. In a similar study with the same montage parameters but greater number of stimulation sessions (i.e., 20 active, 20 sham), Martens et al. (20) measured CSR-R scores and documented moderate improvement effects in patients with TBI, $44 \%$ percent of whom were identified as having consciousness impairments. Thibaut et al. (21) also reported significant improvements on CSR-R total scores as a result of two sessions of tDCS to the left dorsolateral prefrontal cortex in patients who were minimallyconscious but not in those who were in a vegetative state. Similar results were obtained by Bai et al. (22). Some studies documented these improvements lasting for one-week after the last stimulation session (23). These double-blind studies contributed to the clinical use of tDCS in this particular TBI subgroup. Nevertheless, because the severity and nature of pathophysiology in TBI can vary significantly among patients, the findings from these studies must be interpreted in light of the specific population studied. 
Taken together, these findings indicate neuromodulationinduced cognitive improvements may be possible in patients with TBI; however, more research is needed to elucidate its effectiveness for specific patient subgroups.

\section{Cerebrovascular Accident (CVA) Studies}

In addition to TBI populations, neuromodulation methods have been widely employed with patients recovering from CVAs or stroke. The focus of neuromodulation research has been primarily on the rehabilitation of speech and language abilities. These studies have been especially informative regarding stimulus application parameters such as timing and current frequency. In one study of normal subjects, tDCS was found to improve speech motor learning when applied before the speech motor practice session, but not during the practice session (24). In other studies with healthy adults, significant effects of tDCS on semantic wordretrieval and semantic processing were also documented $(25,26)$. In post-stroke patients, however, these effects are inconsistent. Buchwald et al. (10), found that although patients with chronic stroke receiving robotic arm therapy improved measures of speech and language in the absence speech or language therapy, there was no additional benefit of tDCS. The subjects in their study assigned to the sham tDCS condition improved as much as the active tDCS group in measures including diadochokinetic scores and average performance on a comprehensive speech and language battery. On a category naming task, the group assigned to the sham tDCS condition improved significantly more than the active tDCS condition, indicating that active tDCS might potentially hinder recovery on category naming skills. Thus, robotic arm therapy alone helped post-stroke patients improve their speech and language skills but tDCS did not. Likewise, in a randomized control trial, Heikkinen et al. (11) investigated the combined effects of rTMS and intensive language-action therapy in patients with chronic aphasia and found that rTMS provided no additional benefit (11). Rubi-Fessen et al. (27) reported different findings. In their randomized and blinded study, they found a positive effect of rTMS on linguistic skills and functional communication in subacute patients with aphasia compared with a sham condition after a 10-day treatment period (27). It is important to note that all of the patients in their study received speech and language therapy along with rTMS. Chieffo et al. (28) also conducted a randomized study with double-blinding and found that chronic post-stroke patients exhibited significant improvements in picture naming after a single high-frequency (i.e.10 Hz) excitatory TMS application to the right hemisphere homologue of Broca's area. These significant results were not found for the low frequency (i.e. $1 \mathrm{~Hz}$ ) inhibitory condition. All participants in their study completed the naming task both before and after the stimulation session.

The use of neuromodulation has also been implicated for understanding attentional processes in human cognition (29). Clinical studies investigated the potential of neuromodulation to alleviate attentional deficits such as spatial neglect associated with stroke. In a randomized controlled trial of patients with subacute stroke, Cha and Kim (30) found significant improvements with large effect sizes in measures of unilateral neglect including a line bisection test and the Albert test (31). All patients in their study received traditional rehabilitation in addition to TMS, five days per week for one month. To specifically investigate the impact of the number of stimulation sessions on remediation of neglect symptoms in patients with stroke, Kim et al. (31) compared one session of low-frequency TMS with 10 sessions of low-frequency TMS. Their results showed significant improvements in line bisection, letter cancellation, and Ota's task in the group that received 10 sessions compared with the one session group $(31,32)$. To examine the effects of different cortical stimulation parameters and excitability patterns in post-stroke patients, Yang et al. (33) compared three different TMS conditions. The three conditions they included were (1) low-frequency (i.e., $1 \mathrm{~Hz}$ ), (2) high-frequency (i.e., $10 \mathrm{~Hz}$ ), and (3) continuous theta-burst stimulation. Patients in all three groups improved significantly in the line bisection and star cancellation tests at the end of a one-month treatment session compared with patients in the sham group. The largest improvement was found in the group receiving continuous theta-burst stimulation. Similar effects of continuous theta-burst stimulation in combination with behavioral treatments on restoring attentional deficits of patients with stroke were reported by $\mathrm{Fu}$ et al. (34) in their randomized controlled study. Szaflarski et al. (35) found small but significant effects of intermittent theta-burst stimulation when combined with a modified version of constraint-induced language therapy in patients with chronic aphasia.

Overall, evidence on the use of tDCS and TMS in the rehabilitation of post-stroke patients is mixed. More research is needed to establish the validity of these techniques for the rehabilitation of cognitive impairments associated with stroke. Future clinical research should design studies with a special consideration given to the diversity of cognitive impairments in patients with stroke. Given these caveats, neuromodulation techniques should be considered as an adjuvant to cognitive and behavioral therapies in post-stroke patients.

\section{Conclusion}

There is a growing body of research investigating the ability of neuromodulation to ameliorate adverse effects associated with various neurologic conditions. Some evidence indicates TMS and tDCS induced cortical stimulation may be useful for enhancing cognitive skills in healthy individuals, but evidence to support their use in neurologic disorders is weaker. Whether these techniques can be effective at mitigating cognitive impairments associated with disorders may depend on the nature and extent of neurologic involvement. The methodologic variability (e.g. the number and duration of sessions, montages, current density) across studies complicates the process of reconciling findings. More research is needed to establish the reliability of neuromodulation when used in isolation for specific subgroups of patients and to determine optimal stimulation parameters for prolonging neuroplasticity effects. Future avenues of research should also investigate individual differences across patients including genetic and behavioral predictors to delineate the best candidates for these therapies. Moreover, evidence for the use of TMS and tDCS in neurorehabilitation is variable and thus neuromodulation should only be used secondarily to cognitive and physical intervention.

\section{Acknowledgements}

I would like to thank Prof. Dr. Sezer Komşuoğlu for her feedback on this article. 


\section{Ethics}

Peer-review: Externally and internally peer-reviewed.

Financial Disclosure: The author declared that this study received no financial support.

\section{References}

1. Merzenich MM. Soft-Wired: How the New Science of Brain Plasticity Can Change Your Life. San Francisco: Parnassus Publishing; 2013.

2. Krishnan VS, Shin SS, Belegu V, et al. Multimodal evaluation of TMS induced somatosensory plasticity and behavioral recovery in rats with contusion spinal cord injury. Front Neurosci 2019;13:387.

3. Legrand M, Troubat R, Brizard B, et al. Prefrontal cortex rTMS reverses behavioral impairments and differentially activates c-Fos in a mouse model of post-traumatic stress disorder. Brain Stimul 2019;12:87-95.

4. Lu H, Kobilo T, Robertson C, et al. Transcranial magnetic stimulation facilitates neurorehabilitation after pediatric traumatic brain injury. Sci Rep 2015;5:14769.

5. Shin SS, Krishnan V, Stokes W, et al. Transcranial magnetic stimulation and environmental enrichment enhances cortical excitability and functional outcomes after traumatic brain injury. Brain Stimul 2018;11:1306-1313.

6. Bjekić J, Čolić MV, Živanović M, Milanović SD, Filipović SR. Transcranial direct current stimulation (tDCS) over parietal cortex improves associative memory. Neurobiol Learn Mem 2019;157:114-120.

7. Curtin A, Ayaz H, Tang Y, et al. Enhancing neural efficiency of cognitive processing speed via training and neurostimulation: An fNIRS and TMS study. Neuroimage 2019;198:73-82.

8. Jones KT, Peterson DJ, Blacker KJ, Berryhill ME. Frontoparietal neurostimulation modulates working memory training benefits and oscillatory synchronization. Brain Res 2017;1667:28-40.

9. Luber B, Lisanby SH. Enhancement of human cognitive performance using transcranial magnetic stimulation (TMS). Neuroimage 2014;85:961-970.

10. Buchwald A, Falconer C, Rykman-Peltz A, et al. Robotic Arm Rehabilitation in chronic stroke patients with aphasia may promote speech and language recovery (but effect is not enhanced by supplementary tDCS). Front Neurol 2018;9:853.

11. Heikkinen PH, Pulvermüller F, Mäkelä JP, et al. Combining rTMS With intensive language-action therapy in chronic aphasia: A randomized controlled trial. Front Neurosci 2019;12:1036.

12. Fregni F, Boggio PS, Valle AC, et al. A sham-controlled trial of a 5-day course of repetitive transcranial magnetic stimulation of the unaffected hemisphere in stroke patients. Stroke 2006;37:2115-2122.

13. Peterchev AV, Wagner TA, Miranda PC, et al. Fundamentals of transcranial electric and magnetic stimulation dose: Definition, selection, and reporting practices. Brain Stimul 2012;5:435-453.

14. Stagg CJ, Nitsche MA. Physiological basis of transcranial direct current stimulation. Neuroscientist 2011;17:37-53.

15. Priori A, Hallett $M$, Rothwell JC. Repetitive transcranial magnetic stimulation or transcranial direct current stimulation? Brain Stimul 2009;2:241-245.

16. Marr AL, Coronada VG. Central nervous system injury surveillance data submission standards-2002. Atlanta: Dept. of Health and Human Services (US), Centers for Disease Control and Prevention, National Center for Injury Prevention and Control; 2004.

17. Neville IS, Zaninotto AL, Hayashi CY, et al. Repetitive TMS does not improve cognition in patients with TBI: A randomized double-blind trial. Neurology 2019;93:e190-e199.

18. Ulam F, Shelton C, Richards L, et al. Cumulative effects of transcranial direct current stimulation on EEG oscillations and attention/working memory during subacute neurorehabilitation of traumatic brain injury. Clin Neurophysiol 2015;126:486-496.

19. Estraneo A, Pascarella A, Moretta P, et al. Repeated transcranial direct current stimulation in prolonged disorders of consciousness: A double-blind cross-over study. J Neurol Sci 2017;375:464-470.

20. Martens G, Lejeune N, O'Brien AT, et al. Randomized controlled trial of home-based 4-week tDCS in chronic minimally conscious state. Brain Stimulation 2018;11:982-990.

21. Thibaut A, Bruno MA, Ledoux D, Demertzi A, Laureys S. tDCS in patients with disorders of consciousness: Sham-controlled randomized double-blind study. Neurology 2014;82:1112-1118.

22. Bai Y, Xia X, Kang J, et al. TDCS modulates cortical excitability in patients with disorders of consciousness. Neuroimage Clin 2017;15:702-709.

23. Thibaut A, Wannez S, Donneau AF, et al. Controlled clinical trial of repeated prefrontal tDCS in patients with chronic minimally conscious state. Brain Inj 2017;31:466-474.

24. Buchwald A, Calhoun H, Rimikis S, et al. Using tDCS to facilitate motor learning in speech production: The role of timing. Cortex 2019;111:274285.

25. Meinzer M, Lindenberg R, Sieg MM, et al. Transcranial direct current stimulation of the primary motor cortex improves word-retrieval in older adults. Front Aging Neurosci 2014;6:253.

26. Brückner S, Kammer T. Both anodal and cathodal transcranial direct current stimulation improves semantic processing. Neuroscience 2017;343:269275.

27. Rubi-Fessen I, Hirschfeld R, Thiel A, et al. Stimulating communication? The combination of language therapy and repetitive transcranial magnetic stimulation (rTMS) enhances improvement of functional communication and linguistic skills in patients with subacute aphasia. Aphasiology 2018;32:6263.

28. Chieffo R, Ferrari F, Battista P, et al. Excitatory deep transcranial magnetic stimulation with h-coil over the right homologous broca's region improves naming in chronic post-stroke aphasia. Neurorehabil Neural Repair 2014;28:291-298.

29. Banerjee S, Shrey Grover S, Sridharan D. Unraveling Causal Mechanisms of Top-Down and Bottom-Up Visuospatial Attention with Non-invasive Brain Stimulation. J Indian Inst Sci 2019;97:451-475.

30. Cha HG, Kim MK. Effects of repetitive transcranial magnetic stimulation on arm function and decreasing unilateral spatial neglect in subacute stroke: A randomized controlled trial. Clin Rehabil 2016;30:649-656.

31. Kim YK, Jung JH, Shin SH. A comparison of the effects of repetitive transcranial magnetic stimulation (rTMS) by number of stimulation sessions on hemispatial neglect in chronic stroke patients. Experimental Brain Res 2015;233:283-289.

32. Ota H, Fujii T, Suzuki K, Fukatsu R, Yamadori A. Dissociation of body-centered and stimulus-centered representations in unilateral neglect. Neurology 2001;57:2064-2069.

33. Yang W, Liu TT, Song X, et al. Comparison of different stimulation parameters of repetitive transcranial magnetic stimulation for unilateral spatial neglect in stroke patients. J Neurol Sci 2015;359:219-225.

34. Fu W, Cao L, Zhang Y, et al. Continuous theta-burst stimulation may improve visuospatial neglect via modulating the attention network: a randomized controlled study. Top Stroke Rehabil 2017;24:236-241.

35. Szaflarski JP, Griffis J, Vannest J, et al. A feasibility study of combined intermittent theta burst stimulation and modified constraintinduced aphasia therapy in chronic post-stroke aphasia. Restor Neurol Neurosci 2018;36:503-518. 